\title{
AOR
}

Selected Papers of \#AoIR2018:

The $19^{\text {th }}$ Annual Conference of the

Association of Internet Researchers

Montréal, Canada / 10-13 October 2018

\section{'ANNE GOES ROGUE FOR ABORTION RIGHTS!' EXPLORING DISCURSIVE MATERIALIZATION ACROSS AND BEYOND ONLINE PLATFORMS}

\author{
David Myles \\ Université de Montréal
}

This presentation examines the social media campaign \#Support/slandWomen that was undertaken by reproductive rights activists in Prince Edward Island (PEI), the last Canadian province to offer abortion services. The initiative gained popularity in 2016 due to both the off- and online circulation of posters throughout PEI landmarks depicting the Green Gables-like image of a young girl ("rogue Anne") wearing red braids and a bandana. These posters showcased specific hashtags that encouraged debates on various online platforms, like \#HeyWade (referring to Wade MacLauchlan, Prime Minister of PEI), \#AccessNow, \#ItsTime, and \#SupportlslandWomen. While initial debates focused on abortion, conversations swiftly changed to address the suitability of invoking Anne of Green Gables - an important cultural and economic figure in PEI - for political purposes. Indeed, this strategy was instantly criticized by pro-life supporters, some claiming that "abortion activists on Prince Edward Island have hit a new low in their activism by attempting to co-opt the world's most beloved spunky life-loving heroine" (Baklinski, 2016).

Our presentation is part of a larger body of studies that underline the role of social media in the configuration of new modes of political action (Highfield, 2017). Overall, it addresses how women and feminist movements appropriate social media to advocate for human and reproductive rights. In recent years, researchers have taken a specific interest in Twitter and its role in the creation of networked publics surrounding women's issues, what is sometimes referred to as 'hashtag activism' (Williams, 2015) or 'hashtag feminism' (Loza, 2014). This presentation draws from and contributes to these studies by examining more closely how hashtags are embedded in larger discursive practices.

Drawing from sociomaterial approaches (Orlikowski, 2007) and actor-network theory (Latour, 2005), we define the notion of 'discursive practice' as a nexus of various actors (both human/nonhuman, symbolic/material) that intervene in interaction and generate

Suggested Citation (APA): Myles,D. (2018, October 10-13 'Anne Goes Rogue For Abortion Rights!' Exploring Discursive Materialization Across And Beyond Online Platforms. Paper presented at AolR 2018: The 19th Annual Conference of the Association of Internet Researchers. Montréal,

Canada: AolR. Retrieved from http://spir.aoir.org. 
certain effects. For this presentation, we use our case study to understand how prochoice activists invoked the symbolic 'figure' of rogue Anne to give weight to their own arguments by speaking or acting in her name. By 'figure', we mean any symbolic entity that is materialized through interaction and that possesses agency, or the ability to make a significant difference in interaction (Cooren, 2013). As Cooren (2013) argues: "on a rhetorical level, any political project should engage in creating or proposing new configurations, that is new associations and dissociations between figures and other symbolic entities". Hence, our study examined the processes through which the figure of rogue Anne was made present in interaction, the role of digital (online) and physical (offline) affordances in the materialization of this figure, and the differentiated effects that these invocations generated (like countering, defining, (re)framing, publicizing, denying, etc.).

For this exploratory case study, we built our dataset by performing non-participant observation on social media platforms (mainly Instagram and Twitter) and by conducting an online search in Canadian blogs and newspapers. Our dataset contains 7 newspaper articles, 9 blog entries, and 1 radio interview. It is also composed of hashtag related materials that were extracted manually from Twitter (71 pictures and 310 tweets) and from Instagram (34 pictures) that were converted to PDF. We later conducted organizational discourse analysis (Cooren, 2015), which contends that social reality is organized and performed via discourse and through its materialization. From a pragmatic perspective, we examined how discourses perform certain things, mainly the (re)framing of: (1) bodies, as well as (2) space and time.

First, our results show that invoking the figure of rogue Anne allowed for pro-choice collectives to assert their authority in abortion debates by labelling the fictional character as a modern feminist icon. On the one hand, such discursive association (Anne would have been for abortion) helped pro-choice collectives to gain a body, as Anne became the embodiment, the incarnation of their campaign. This was observed through the use of various images depicting the body of rogue Anne as being the body of all PEI women (Get your government off my body). This relates more generally to the politicization of female bodies which is a major issue in most abortion debates. On the other hand, if invoking the figure of rogue Anne helped pro-choice collectives to give their movement an identity, it also gave Anne herself (the female character, the young woman) a political and bandana-wearing body. Indeed, it reframed the character as a contemporary woman with full claim over her own reproductive rights. Hence, as a symbolic figure, our case study shows that Anne is as much speaking through activists as they are speaking in her name, thus enacting the polyphonic nature of discourse.

Second, our results also show that invoking the figure of rogue Anne contributed in reframing space, particularly when it was used on posters that were distributed in offand online settings. For example, the display of posters throughout PEI landmarks reframed everyday public places (like the Founders' Hall in Charlottetown) and objects (like statues of historical male figures dressed with rogue Anne's physical attributes) as political ones, effectively bringing PEl's male-dominated historical artefacts into a 
present-day conversation about reproductive rights. Furthermore, these posters were also used as a countdown to PEl's council vote ( 9 days left) which relied on temporal hashtags to help gain momentum (\#ItsTime) and engage in a conversational mode (\#HeyWade) that took place across platforms (Twitter, Instagram, etc.) and beyond (in the streets, in public spaces, in newspapers, etc.).

Thus, our results underline the importance of studying the intervention of symbolic figures, their effects, and the situated context of their materialization within political initiatives that incorporate and go beyond the practice of 'hashtagging'. Furthermore, and in line with previous work on counterpublics (Fraser, 1990), there is a need to understand not only how emerging publics are formed, but also how dominant discourses are countered by activists through language practices. To do so, researchers should continue to document political struggles while focusing on the establishment of new relations through discourse between symbolic entities that challenge the status quo (rogue Anne as a feminism icon, Anne of Green Gables as a symbol for the protection of life, etc.) and by examining how affordances of off- and online settings sustain such practices.

\section{References}

Baklinski, P. (2016). "Yuck! PEI abortion advocates co-opt life-loving Anne of Green Gables to push abortion". Life Site News. Online. $<w w w$.lifesitenews.com/opinion/yuck-pei-abortion-advocates-co-opt-life-lovinganne-of-green-gables-to-push>.

Cooren, F. (2013). Manières de faire parler. Interaction et ventriloquie. Bord de l'eau (Le).

Cooren, F. (2015). Organizational discourse: Communication and constitution. John Wiley \& Sons.

Fraser, N. (1990). Rethinking the public sphere: A contribution to the critique of actually existing democracy. Social text, (25/26), 56-80.

Highfield, T. (2017). Social media and everyday politics. John Wiley \& Sons.

Latour, B. (2005). Reassembling the social: An introduction to actor-network-theory. Oxford university press.

Loza, S. (2014). Hashtag feminism,\# SolidaritylsForWhiteWomen, and the other\# FemFuture. Ada: A Journal of Gender, New Media, and Technology, 5.

Orlikowski, W. J. (2007). Sociomaterial practices: Exploring technology at work. Organization studies, 28(9), 1435-1448.

Williams, S. (2015). Digital defense: Black feminists resist violence with hashtag activism. Feminist Media Studies, 15(2), 341-344. 